\title{
Origin, composition and nutritional quality of particulate matter at deep-sea hydrothermal vents on Axial Volcano, NE Pacific
}

\author{
Christian Levesque $^{1,2,3, *}$, Helene Limén ${ }^{1}$, S. Kim Juniper ${ }^{1,2}$ \\ ${ }^{1}$ Centre de recherche en géochimie et en géodynamique (GEOTOP), and ${ }^{2}$ Département des sciences biologiques, Université \\ du Québec à Montréal, CP 8888, Succursale Centre-Ville, Montréal, Québec H3C 3P8, Canada \\ ${ }^{3}$ Present address: Monterey Bay Aquarium Research Institute, 7700 Sandholdt Road, Moss Landing, California 95039, USA
}

\begin{abstract}
Deep-sea hydrothermal vent communities are supported by local microbial chemolithoautotrophic production. While nutritional symbiotic associations between microbial primary producers and their metazoan hosts are well characterised, food sources used by the diverse and abundant non symbiont-containing vent species remain poorly known. Vent suspension- and deposit-feeders are usually considered as primary consumers directly relying on free-living microbial primary production, but other sources of particulate organic matter (POM) may also be part of their diet. We investigated the origin, composition and nutritional quality of POM at Axial Volcano (NE Pacific) vents, using microscopic observations, stable isotopic and biochemical analyses. A positive correlation between the stable carbon isotopic composition of POM and that of vent fluid dissolved inorganic carbon (DIC) indicates that the bulk of vent particulate organic carbon is derived from the local chemolithoautotrophic fixation of vent DIC. Low estimates of bacterial and total microbial carbon might reflect a rapid turnover of free-living bacterial biomass in the vent ecosystem. The low microbial fraction, together with the presence of abundant debris, point to the existence of a large detrital fraction in the POM pool. This implies that the previously largely overlooked detrital compartment may be a significant part of the diet of consumers, and that organic matter recycling may be a major process in these ecosystems.
\end{abstract}

KEY WORDS: Hydrothermal vents · Axial Volcano $\cdot$ Particulate organic matter $\cdot$ Detritus $\cdot$ Nutritional quality $\cdot$ Consumers $\cdot$ Food web

\section{INTRODUCTION}

Deep-sea hydrothermal vents are island habitats harbouring high levels of faunal biomass in the otherwise resource-starved deep-sea environment. This rich vent fauna is supported by local microbial chemolithoautotrophic production, in particular through oxidation of reduced sulphur and iron from the hydrothermal fluid (Karl 1995). One component of the vent fauna directly exploits microbial primary production by hosting endosymbiotic bacteria. This is the case for the vestimentiferan tubeworms, clams and mussels that constitute a large part of the biomass at hydrothermal vents in the eastern Pacific Ocean (Fisher 1995, Sarrazin \&
Juniper 1999). However, the greater portion of the vent faunal diversity and organism abundance is constituted by non symbiont-containing (NSC) organisms such as polychaetes and gastropods (Sarrazin et al. 1997, 1999, Tunnicliffe et al. 1998, Tsurumi \& Tunnicliffe 2003). These organisms are often assumed to directly rely on a diet of free-living autotrophic microorganisms. Although there remains little doubt that chemolithoautotrophic bacteria and archaea constitute the base of vent NSC food chains (Karl 1995), a direct trophic link between these microbes and NSC metazoa, while often presumed, has never been thoroughly tested. In fact, many of these species feed on particulate organic matter (POM) through suspension- and deposit-feeding, as 
evidenced by behavioural and morphological observations (Desbruyères \& Laubier 1986, Tunnicliffe et al. 1993, Grelon 2001, Morineaux et al. 2002), gut content examinations (McHugh 1987, Tunnicliffe et al. 1993, Chevaldonné 1996) and stable isotope analyses (Van Dover \& Fry 1994, Colaço et al. 2002, C. Levesque, S. K. Juniper \& H. Limén unpubl. data). In addition to autotrophic microbes, other particulate organic constituents are present in the vent environment, including heterotrophic bacteria and archaea, protists, micrometazoa and detrital organic matter of local and allochthonous origin (Brault 1984, Brault et al. 1984, Comita et al. 1984, Albéric 1986, Daumas et al. 1988, Karl 1995, Levesque \& Juniper 2002). As feeding on POM is apparently an important trophic strategy at vents, a thorough description of vent-associated POM is essential to elucidate the trophic position of vent NSC species, and to expand our general understanding of the functioning of vent food webs. The aim of this study was to trace the origin, describe the composition and assess the nutritional quality of POM at hydrothermal vents on Axial Volcano, northeast Pacific.

\section{MATERIALS AND METHODS}

Study site. Axial Volcano is located on the central segment of the Juan de Fuca Ridge (NE Pacific) at $46^{\circ} 55^{\prime} \mathrm{N}, 130^{\circ} 00^{\prime} \mathrm{W}$ (Fig. 1). The volcano is capped by a $3 \times 8 \mathrm{~km}$ horseshoe-shaped caldera (depth $\sim 1500 \mathrm{~m}$ ) where extensive hydrothermal venting occurs at 3 known vent fields: ASHES (Axial Seamount Hydrothermal Emissions Study), the South Rift Zone (SRZ) and CASM (Chase et al. 1985, Embley et al. 1990).

Nineteen active hydrothermal vent sites (12 in the SRZ, 6 at ASHES vent field and 1 at CASM vent field) were visited at Axial Volcano during New Millennium Observatory (NeMO) project cruises in September 1998, June to July 1999, June to July 2000, and July 2001 (Table 1). Some sites were visited more than once, and altogether samples represented 30 site-year combinations. As a point for comparison, 6 non-vent sites with deposits of pelagic sediment (at least $200 \mathrm{~m}$ away from any known vent) were sampled.

All vent sites, except 3 , were $\sim 1$ to $10 \mathrm{~m}$ wide areas on the basaltic seafloor where warm (mean temperature $=19.1^{\circ} \mathrm{C}, \mathrm{SE}=2.2^{\circ} \mathrm{C}, \mathrm{n}=29$ ), diffuse hydrothermal fluid was issuing from the oceanic crust. The remaining 3 sites were hosted on sulphide edifices bathed in diffuse vent fluid. All sites supported endemic vent faunal assemblages composed mainly of alvinellid polychaetes, gastropods and vestimentiferan tubeworms (see Tsurumi et al. 1998, Tsurumi 2001 and Marcus 2003 for detailed descriptions of the faunal assemblages of these sites).
Among the 12 SRZ sites, 7 were located on a lava flow formed by a January-February 1998 eruption (Embley et al. 1999). The age of these nascent sites was therefore known with precision. The remaining 5 sites

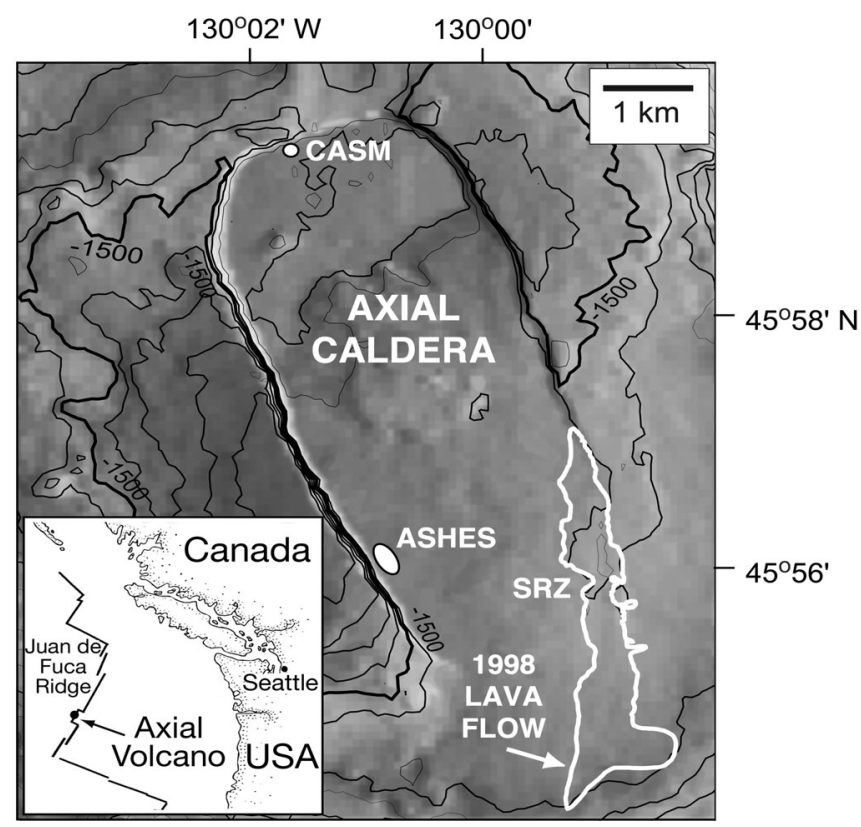

Fig. 1. Location of the ASHES (Axial Seamount Hydrothermal Emissions Study), CASM (Canadian American Seamount Expedition) and SRZ (South Rift Zone) vent fields on Axial Volcano, Juan de Fuca Ridge, NE Pacific. The extent of the January-February 1998 lava flow in the SRZ is outlined

Table 1. Sampling sites and years at the SRZ, ASHES and CASM hydrothermal vent fields on Axial Volcano. SRZ sites located on the 1998 lava flow are labelled as SRZ (lava). See Fig. 1 for explanation of vent field names

\begin{tabular}{|llcccc|}
\hline Site & Location & 1998 & 1999 & 2000 & 2001 \\
\hline Cloud (N4) & SRZ (lava) & & $\bullet$ & & \\
Cloud (N6) & SRZ (lava) & & $\bullet$ & $\bullet$ & $\bullet$ \\
Marker 33 & SRZ (lava) & $\bullet$ & $\bullet$ & $\bullet$ & \\
Marker 108 & SRZ (lava) & $\bullet$ & & & \\
Marker N41 & SRZ (lava) & & & $\bullet$ & $\bullet$ \\
Nascent & SRZ (lava) & & $\bullet$ & $\bullet$ & $\bullet$ \\
Snail (N8) & SRZ (lava) & $\bullet$ & $\bullet$ & & \\
Bag City & SRZ & & $\bullet$ & & \\
Coquilles & SRZ & & $\bullet$ & & \\
Joystick & SRZ & & $\bullet$ & & $\bullet$ \\
Marker 113 & SRZ & & & & \\
Old Worms & SRZ & & $\bullet$ & $\bullet$ & $\bullet$ \\
Gollum & ASHES & $\bullet$ & $\bullet$ & & \\
Hairdo & ASHES & $\bullet$ & & & \\
Medusa-base & ASHES & $\bullet$ & & & \\
Medusa-top & ASHES & $\bullet$ & & & \\
Phoenix & ASHES & & $\bullet$ & & \\
Pork Chop & ASHES & & $\bullet$ & & \\
T\&S & CASM & & $\bullet$ & \\
\hline
\end{tabular}


in the SRZ were located 50 to $200 \mathrm{~m}$ beyond the limits of the lava flow. Vent assemblages at these latter SRZ sites, as well as in the ASHES and CASM vent fields, pre-dated those at the nascent sites, but their approximate age could not be determined.

Sampling. The remotely-operated vehicle ROPOS was used for all sampling. Temperature at vent openings was recorded with temperature probes on the SUAVE fluid sampler (Massoth et al. 1991), the Hot Fluid Sampler (D. Butterfield, University of Washington \& Pacific Marine Environmental Laboratory, Seattle, WA, USA), or by a thermistor mounted on the inlet of the ROPOS suction sampling device. The maximum venting fluid temperature reached during the observations ( 3 to $10 \mathrm{~min}$ ) was recorded.

Particulate matter: Particulate matter (PM) was collected with a suction-sampling device that pumped water into 21 acrylic jars. Two layers of $200 \mu \mathrm{m}$ Nitex nylon mesh at the outflow of each jar allowed sufficient flow to provide suctioning capability, yet avoid forcing soft particulates through the filter mesh. Sample accumulation in the suction jars was monitored with the ROPOS colour video camera. Suction was maintained until the filter mesh was visibly clogged and the flow rate substantially diminished. Operated in this manner, and at low to moderate flow rates, the suction sampler acted as a broad spectrum concentrator of particles and attached bacteria, rather than as an in situ filtration system for $>200 \mu \mathrm{m}$ particles. Finer mesh filters clogged too quickly to permit collection of enough material for analyses. During sampling, the suction intake was held in the centre of tubeworm assemblages or, for the non symbiont-containing fauna, slowly swept over the substratum within the faunal assemblage. At non-vent sites, sediments were sampled using the same device. One jar and mesh set were used for each sample, and the collection hose was flushed with bottom seawater between samples to avoid cross-contamination. Samples remained at ambient bottom temperature $\left(\sim 2^{\circ} \mathrm{C}\right)$ in closed jars until brought to the surface at the end of the dive.

On board the ship, PM was left to settle in the jars for 30 to $60 \mathrm{~min}$ at $4{ }^{\circ} \mathrm{C}$. Duplicate aliquots of PM were immediately taken for ATP determinations (see procedure below), for fixation in cacodylate-buffered glutaraldehyde ( $3 \%$ final concentration) and for fixation in seawater-buffered formalin (7\% final concentration). Remaining sample material was frozen $\left(-80^{\circ} \mathrm{C}\right)$ in polypropylene tubes or collected on pre-combusted $\left(500^{\circ} \mathrm{C}\right) \mathrm{GF} / \mathrm{F}$ or $\mathrm{GM} / \mathrm{F}$ glass fibre filters before freez$\operatorname{ing}\left(-80^{\circ} \mathrm{C}\right)$.

At the land-based laboratory, frozen samples were thawed at $4{ }^{\circ} \mathrm{C}$. Macrofauna, meiofauna and recognisable parts of organisms (mainly polynoid scales, polychaete branchial filaments and gastropod shells) visi- ble under a $60 \times$ binocular microscope were removed from the particulate matter.

Vent particulate matter (PM) is defined herein as the material collected from the vent assemblages and processed as described above. Particulate organic matter (POM) refers to the organic fraction of the PM.

Dissolved inorganic carbon: Vent fluid was collected at the vent openings in 21 acrylic jars using the ROPOS suction sampler. The jars were kept closed until brought on board, where the fluid was immediately subsampled by immersing $125 \mathrm{ml}$ polypropylene bottles in the jars. Immersion of the bottles in the jars prevented sub-sampling of the fluid in contact with the atmosphere, thereby minimising any potential effect of equilibration with atmospheric $\mathrm{CO}_{2}$ on the stable isotopic composition of DIC. Three drops of saturated $\mathrm{HgCl}_{2}$ were added to the bottles to stop microbial activity. The bottles were capped, sealed with PVC tape, and kept at $4^{\circ} \mathrm{C}$ until analysed for dissolved inorganic carbon (DIC) stable isotopic composition.

Light and scanning electron microscopy. Light microscopy (at 65 to $400 \times$ magnification) and scanning electron microscopy were used to study particulate matter composition. Glutaraldehyde-preserved samples were freeze-dried, sputter-coated with gold, and observed with a Hitachi S-2300 scanning electron microscope and a Hitachi S-4300SE/N field emission, variable pressure scanning electron microscope. Elemental composition of observed structures was analysed by energy-dispersive X-ray analysis (EDX). The global composition of 7 samples was also analysed by EDX.

Stable isotope analyses. In order to trace the origin of particulate organic matter, the stable carbon and nitrogen isotopic compositions of POM and DIC were analysed. POM aliquots for stable carbon isotope determination were acidified with $0.1 \mathrm{~N} \mathrm{HCl}$ to remove carbonates. Vent fluid samples were acidified with phosphoric acid to convert DIC to $\mathrm{CO}_{2}$, which was analysed for its stable carbon isotopic composition. Stable isotopic compositions were analysed with a Micromass Isoprime isotope ratio mass spectrometer and are reported as follows:

$$
\delta X=\left[\left(R_{\text {sample }} / R_{\text {standard }}\right)-1\right] \cdot 1000(\%)
$$

where $X$ is ${ }^{13} \mathrm{C}$ or ${ }^{15} \mathrm{~N}$, and $R$ is ${ }^{13} \mathrm{C} /{ }^{12} \mathrm{C}$ or ${ }^{15} \mathrm{~N} /{ }^{14} \mathrm{~N}$ (Ehleringer \& Rundel 1989). Standards used were Vienna Pee-Dee Belemnite (VPDB) for carbon and atmospheric $\mathrm{N}_{2}$ for nitrogen.

Biochemical analyses. Nutritional quality of POM was assessed by measuring available protein and total lipid contents, 2 important nutritional components for metazoa (e.g. Mayer et al. 1986, Grémare et al. 1997), as well as the $\mathrm{C}: \mathrm{N}$ ratio, which provides information on both the origin and lability of organic matter. Parti- 
culate matter samples were analysed for organic carbon (following treatment with $0.1 \mathrm{~N} \mathrm{HCl}$ ) and nitrogen contents using a Carlo-Erba $\mathrm{CN}$ analyser. Available (hydrolysable) protein content was measured colorimetrically in triplicate following the reaction with Coomassie Blue dye using the procedure of Mayer et al. (1986), and is reported as bovine serum albumin equivalents. Lipid content was assessed colorimetrically in triplicate using the sulphophosphovanillin method of Barnes \& Blackstock (1973) following lipid extraction as in Folch et al. (1957). The Supelco 37 fatty acid methyl ester mix (Supelco/Sigma-Aldrich) was used as a lipid standard.

Biomass. Bacterial counts and ATP measurements were used to provide estimates of bacterial biomass and total microbial biomass, respectively. Immediately upon recovery of the samples on board, ATP was extracted in duplicate in $6 \mathrm{ml}$ of boiling phosphate buffer (60 mM, pH 7.4; Karl 1993) for $10 \mathrm{~min}$, and the extracts were frozen $\left(-20^{\circ} \mathrm{C}\right)$. At the land-based laboratory, firefly lantern extract was added to the thawed ATP extract and bioluminescence was measured with a Monolight 2010 luminometer (Analytical Luminescence Laboratory). For conversion of ATP to total microbial biomass carbon, the conversion factor of $250 \mathrm{~g} \mathrm{C} \mathrm{g}^{-1}$ ATP was used. This ratio is typically applied to natural microbial communities and reflects the variability in the C:ATP ratio between unicellular microorganisms ( 200 to $\left.350 \mathrm{~g} \mathrm{C} \mathrm{g}^{-1} \mathrm{ATP}\right)$ and micrometazoa (50 to $150 \mathrm{~g} \mathrm{C} \mathrm{g}^{-1}$ ATP; Karl 1980, 1993).

Formalin-preserved samples were DAPI-stained for cell counting by epifluorescence microscopy (Porter \& Feig 1980). DAPI-stained bacteria and archaea cannot be discerned by this method and are both included here in the estimated 'bacterial' abundance. Cell abundance was converted to bacterial biomass carbon using a factor of $10^{-14} \mathrm{~g} \mathrm{C}$ cell $^{-1}$ (Williams \& Carlucci 1976).

As sample volume was limited, all analyses could not be carried out on all samples. Determinations of carbon and nitrogen content, and stable carbon and nitrogen isotopic compositions were performed on all samples, while other assays (available protein and lipid concentrations, ATP determination and DAPI-staining cell counts) were conducted only when sample size was sufficient.

Statistical analyses. Linear regressions were calculated to relate $\delta^{13} \mathrm{C}$ DIC and $\delta^{13} \mathrm{C}$ POM, as well as $\delta^{13} \mathrm{C}$ DIC and temperature. The biochemical composition of POM was compared to that of sediments using the non-parametric Kruskal-Wallis test (non-parametric tests were used when data were not normally distributed according to the Shapiro-Wilks test). Correlations between biochemical parameters were measured by Spearman's rank correlation coefficient. To evaluate temporal variability in POM composition, sites were grouped according to their age in 5 categories $(0.7,1.4$, 2.4, 3.5 yr old nascent sites, and non-nascent sites). Temperature, organic carbon and nitrogen, the C:N ratio, $\delta^{13} \mathrm{C}, \delta^{15} \mathrm{~N}$, protein, lipid, ATP contents and bacterial abundance were compared between these groups using the Kruskal-Wallis test.

\section{RESULTS}

\section{Microscopic observations}

Microscopic observations of Axial Volcano vent particulate matter revealed a complex and heterogeneous composition. Light microscopy at 65 to $400 \times$ magnification showed abundant amorphous particles ( 40 to $500 \mu \mathrm{m})$, parts of alvinellid polychaete tubes and remains of animals (setae, scales, gill filaments). Under scanning electron microscopy, abundant amorphous, grained and filamentous mineral particles (mainly sulphur) were observed (Fig. 2A,B). Amorphous, apparently organic detrital particles ( $\mu \mathrm{m}$ to $\mathrm{mm}$ scale) were ubiquitous. Remains of diatoms and coccolithophorids were also frequent. Epifluorescence microscopic observations of DAPI-stained samples indicated that bacterial cells were dominated by coccoid forms (Fig. $2 \mathrm{C}$ ). Filamentous bacteria ( $\mu \mathrm{m}$-scale diameter) and larger (10 to $20 \mu \mathrm{m}$ ) Beggiatoa-like filaments (Nelson et al. 1989) were also present. Amorphous, non DAPIstaining material was abundant in all samples.

\section{Stable isotopic composition}

Vent POM showed a wide range of $\delta^{13} \mathrm{C}$ values $(-11.4$ to $-26.8 \%$; Table 2$)$. The mean $\delta^{13} \mathrm{C}$ of vent POM (-20.2\%) tended to be enriched in ${ }^{13} \mathrm{C}$ compared to sediments (mean $=-25.0 \%$ ), but this difference was not statistically significant. The $\delta^{15} \mathrm{~N}$ of vent POM (mean $=4.3 \%$ ) was less variable $(2.1$ to $6.7 \%$ ) than the stable carbon isotopic composition, and was significantly lower than the $\delta^{15} \mathrm{~N}$ of sediments (mean $=6.7 \%$; Kruskal-Wallis $\mathrm{p}=0.0034, \mathrm{n}=36$ ).

The stable carbon isotopic composition of vent fluid DIC ranged between -0.7 and $8.1 \%$ and was positively correlated with the $\delta^{13} \mathrm{C}$ of POM $\left(\mathrm{r}^{2}=0.4861\right.$, $\mathrm{p}=0.0117, \mathrm{n}=12 ;$ Fig. 3A) and with fluid temperature at the vent opening $\left(r^{2}=0.4874, p=0.0247, n=10\right.$; Fig. 3B)

\section{Biochemical composition}

Vent particulate matter was mostly inorganic, with sulphur as the dominant constituent element (31 to 

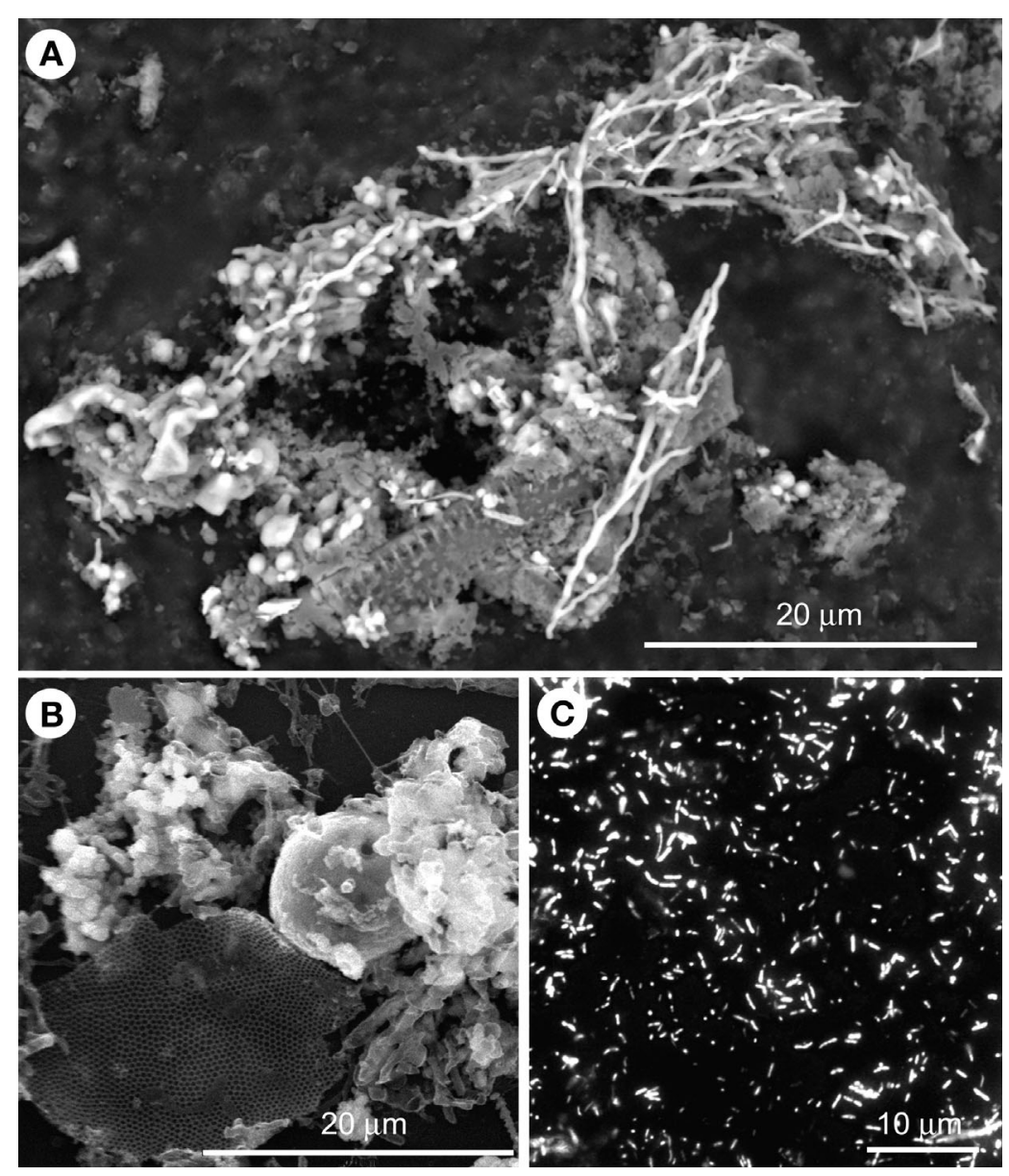

Fig. 2. (A, B) Scanning electron and (C) epifluorescence micrographs of particulate matter from Axial Volcano diffuse vents, showing diatom remains, sulphur filaments and globules, amorphous material (A, B) and DAPI-stained coccoid bacteria (C)
$70 \mathrm{Mol}$ wt \%) followed by iron (19 to $27 \mathrm{Mol}$ wt \%). The silicon content was significant in some samples (up to $18 \mathrm{Mol}$ wt \%). The organic fraction was small, with an average of $4.0 \%$ organic carbon and $0.7 \%$ nitrogen content. In comparison, sediments had a similar organic carbon content $($ mean $=4.2 \%$ ) and a lower nitrogen content (mean $=0.3 \%$, KruskalWallis $\mathrm{p}=0.0258, \mathrm{n}=36$; Table 2).

Despite their similar organic carbon content, vent PM and sediments were clearly different in their biochemical composition. The mean $\mathrm{C}: \mathrm{N}$ ratio measured in vent POM (6.3) was significantly lower than that of sediments (17.4; Kruskal-Wallis: $\mathrm{p}=0.0002, \mathrm{n}=36$; Table 2). Available protein content was highly variable and tended to be larger in vent POM (mean $=227.2 \mathrm{mg} \mathrm{g}^{-1} \mathrm{C}$ ) than in sediments (mean $=31.5 \mathrm{mg} \mathrm{g}^{-1} \mathrm{C}$ ). The average lipid content of vent POM was $39.3 \mathrm{mg} \mathrm{g}^{-1} \mathrm{C}$. Lipids could not be measured accurately in sediments, because clean lipid extracts were not obtained. The ATP content of vent POM (mean $=119.3 \mu \mathrm{g} \mathrm{ATP} \mathrm{g}^{-1} \mathrm{C}$ ) was $\sim 8$ times higher than in sediments (mean $=15.7 \mu \mathrm{g}$ ATP $\mathrm{g}^{-1} \mathrm{C}_{\text {; Kruskal- }}$ Wallis $\mathrm{p}=0.0253, \mathrm{n}=8$ ). Total microbial biomass carbon, estimated from ATP concentrations, represented on average $3.0 \%$ of vent particulate organic carbon. The abundance of DAPI-staining

Table 2. Biochemical composition of vent particulate matter and sediments from Axial Volcano. Mean, standard error (SE) of the mean, range and sample size (n) are given for each variable. Kruskal-Wallis p-values are from comparisons of means between vent particulate matter and sediments. \% $\mathrm{C}_{\text {org }}$ : percent of organic carbon

\begin{tabular}{|c|c|c|c|c|c|c|c|c|c|}
\hline & \multicolumn{4}{|c|}{ - Vent- } & \multicolumn{4}{|c|}{ - Sediment } & \multirow{2}{*}{$\mathrm{p}$} \\
\hline & Mean & $\mathrm{SE}$ & Range & $\mathrm{n}$ & Mean & SE & Range & $\mathrm{n}$ & \\
\hline$\% \mathrm{C}_{\text {org }}$ & 4.0 & 0.5 & $0.3-10.8$ & 30 & 4.2 & 0.9 & $0.4-6.4$ & 6 & $\mathrm{p}=0.7989$ \\
\hline$\% \mathrm{~N}$ & 0.7 & 0.1 & $0.1-1.9$ & 30 & 0.3 & 0.1 & $0.02-0.53$ & 6 & $\mathrm{p}=0.0258$ \\
\hline $\mathrm{C}: \mathrm{N}$ & 6.3 & 0.3 & $3.6-11.3$ & 30 & 17.4 & 2.9 & $10.7-27.2$ & 6 & $\mathrm{p}=0.0002$ \\
\hline$\delta^{13} \mathrm{C}(\%)$ & -20.2 & 0.9 & $-26.8--11.4$ & 23 & -25.0 & 0.4 & $-24.0--25.8$ & 4 & $\mathrm{p}=0.0760$ \\
\hline$\delta^{15} \mathrm{~N}(\%)$ & 4.3 & 0.3 & $2.1-6.7$ & 30 & 6.7 & 0.6 & $4.4-8.1$ & 6 & $\mathrm{p}=0.0034$ \\
\hline Proteins (mg g ${ }^{-1} \mathrm{C}$ ) & 227.2 & 60.6 & $17.0-760.0$ & 14 & 31.5 & 6.3 & $25.2-37.8$ & 2 & $\mathrm{p}=0.1123$ \\
\hline Lipids (mg g $\left.{ }^{-1} \mathrm{C}\right)$ & 39.3 & 14.4 & $1.7-124.4$ & 8 & & & & & \\
\hline ATP $\left(\mu g g^{-1} \mathrm{C}\right)$ & 119.3 & 30.7 & $28.0-180.4$ & 5 & 15.7 & 5.7 & $9.9-27.1$ & 3 & $\mathrm{p}=0.0253$ \\
\hline Microbial C (\% POC) & 3.0 & 0.8 & $0.7-4.5$ & 5 & 0.4 & 0.1 & $0.2-0.7$ & 3 & \\
\hline $\begin{array}{l}\text { DAPI-staining cells } \\
\left(\times 10^{11} \mathrm{~g}^{-1} \mathrm{C}\right)\end{array}$ & 5.4 & 2.1 & $0.1-24.8$ & 12 & 0.6 & 0.3 & $0.03-1.2$ & 3 & $\mathrm{p}=0.0606$ \\
\hline Bacterial C (\% POC) & 0.5 & 0.2 & $0.0-2.5$ & 12 & 0.06 & 0.03 & $0.003-0.12$ & 3 & \\
\hline
\end{tabular}



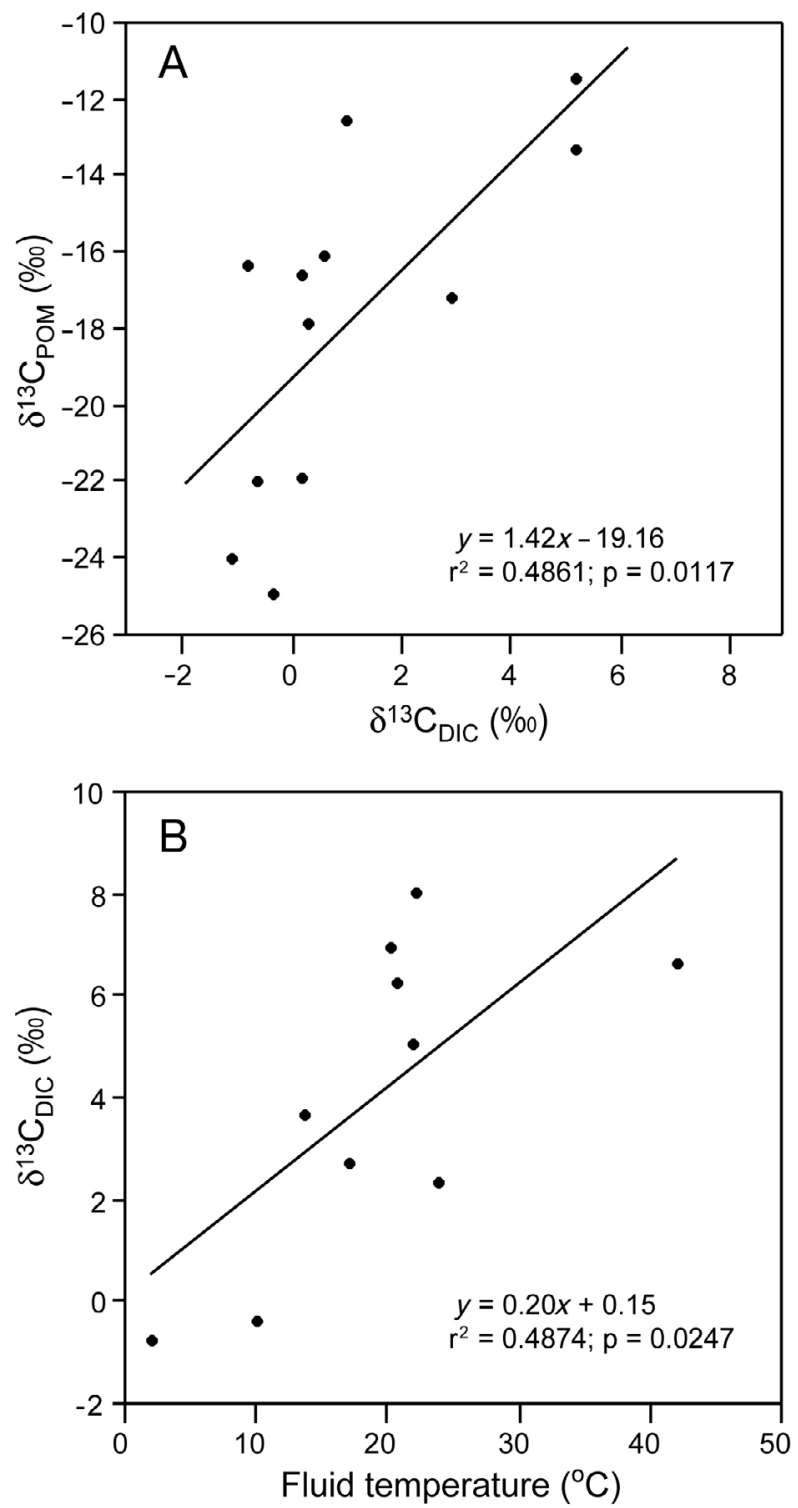

Fig. 3. (A) Linear regression between the stable carbon isotopic composition $\left(\delta^{13} \mathrm{C}\right)$ of particulate organic matter (POM) and that of dissolved inorganic carbon (DIC) at Axial Volcano diffuse vents; (B) linear regression between $\delta^{13} \mathrm{C}$ DIC and fluid temperature at the vent opening

Table 3. Spearman's rank correlation coefficients between POM constituents describing its nutritional quality. Values in bold are statistically significant $(p<0.05)$. ATP was excluded due to low overlap with other measurements

\begin{tabular}{|lcccc|}
\hline & C:N & $\begin{array}{c}\text { Proteins } \\
\left(\mathrm{mg} \mathrm{g}^{-1} \mathrm{C}\right)\end{array}$ & $\begin{array}{c}\text { Lipids } \\
\left(\mathrm{mg} \mathrm{g}^{-1} \mathrm{C}\right)\end{array}$ & $\begin{array}{c}\text { DAPI-staining } \\
\text { cells }\left(\times 10^{11} \mathrm{~g}^{-1} \mathrm{C}\right)\end{array}$ \\
\hline $\mathrm{C}: \mathrm{N}$ & - & & & \\
Proteins $\left(\mathrm{mg} \mathrm{g}^{-1} \mathrm{C}\right)$ & -0.2915 & - & & \\
Lipids $\left(\mathrm{mg} \mathrm{g}^{-1} \mathrm{C}\right)$ & $\mathbf{0 . 7 8 1 8}$ & $\mathbf{0 . 7 6 1 9}$ & - & - \\
DAPI-staining cells & $\mathbf{- 0 . 5 7 9 8}$ & $\mathbf{0 . 4 6 5 4}$ & -0.4524 & \\
$\left(\times 10^{11} \mathrm{~g}^{-1} \mathrm{C}\right)$ & & & & \\
\hline
\end{tabular}

cells in vent POM (mean $=5.4 \times 10^{11}$ cells $\mathrm{g}^{-1} \mathrm{C}$ ) was 1 order of magnitude higher than in sediments (mean $=$ $0.6 \times 10^{11}$ cells $\mathrm{g}^{-1} \mathrm{C}$ ), although this difference was not statistically significant (Kruskal-Wallis $\mathrm{p}=0.0606, \mathrm{n}=$ 15). Estimated bacterial carbon represented a minor fraction $($ mean $=0.5 \%$ ) of the vent particulate organic carbon.

Lipid content of vent POM was positively correlated with both the $\mathrm{C}: \mathrm{N}$ ratio and protein content (Spearman's rho $=0.7818$ and 0.7619, respectively; $\mathrm{p}<0.05$; Table 3). Bacterial abundance was negatively correlated with the C:N ratio (Spearman's $\rho=-0.5798$ ) and positively correlated with protein content (Spearman's $\rho=0.4654 ; \mathrm{p}<0.05$ in both cases).

\section{Temporal variability in particulate matter composition}

Temperature, organic carbon and nitrogen, the C:N ratio, $\delta^{13} \mathrm{C}, \delta^{15} \mathrm{~N}$, protein, lipid, ATP contents and bacterial abundance did not differ significantly between sites of different age groups $(0.7$ to $3.5 \mathrm{yr}$ old nascent sites and non-nascent sites; Kruskal-Wallis p > 0.05 in all cases). Nitrogen content tended to increase at nascent sites from 1998 (0.7 yr) to 2001 (3.5 yr), and the $\mathrm{C}: \mathrm{N}$ ratio tended to decrease accordingly (data not shown). $\delta^{13} \mathrm{C}$ also tended to decrease during the same period. However, variability in the measured parameters was not significantly greater between than within age groups; therefore, data from all age groups will be discussed together.

\section{DISCUSSION}

\section{Origin of vent POM}

The POM stable isotopic composition data distinguish particulate carbon and nitrogen sources at vents from those supplying nearby pelagic sediments (Table 2). The significant positive relationship between $\delta^{13} \mathrm{C}$ POM and $\delta^{13} \mathrm{C}$ DIC (Fig. 3) is a strong indicator that the bulk of vent particulate organic carbon is locally fixed from vent fluid DIC. Even the lowest $\delta^{13} \mathrm{C}$ POM values (overlapping with $\delta^{13} \mathrm{C}$ sediment) can be explained in terms of vent fluid DIC stable isotopic composition (Fig. 3), indicating that these lower values do not necessarily reflect contributions from pelagic sources or advected sediment.

The stable carbon isotopic composition of fluid DIC at Axial Volcano diffuse vents spans a large range $(-0.7$ to $8.1 \%$; Fig. 3) compared to vent sys- 
tems on the Endeavour segment of the same ridge $(-1$ to $1 \%$; C. Levesque unpubl. data). Elsewhere, values range from ca. -4.0 to 3.9 \% (Rau 1981, Fisher 1995), depending on location. To our knowledge, the wide range reported here has not been previously observed on a local scale (within a vent field). The wide range on Axial Volcano may originate from kinetic isotopic fractionation of the $\mathrm{CO}_{2}$-rich fluid due to the relatively shallow depth ( 1500 m) compared to most other deepsea vent systems (e.g.: $\sim 2200 \mathrm{~m}$ for Endeavour segment). Phase separation of high temperature hydrothermal fluids prior to venting produces vapour-rich and brine-rich phases at Axial (Massoth et al. 1989). During this process, kinetic isotopic fractionation of DIC is likely to occur, where isotopically lighter DIC is enriched in the vapour phase, leaving a ${ }^{13} \mathrm{C}$-enriched fluid DIC. Varying dilution of a high temperature source fluid by crustal seawater, the process that forms low-temperature vents, could explain the observed relationship between $\delta^{13} \mathrm{C}$ DIC and temperature. This large range on a local scale provides an unprecedented opportunity to confirm the link between vent DIC and POM.

Diatom and coccolithophorid debris found in all samples show that contributions of allochtonous sources cannot be ignored. However, both the stable isotopic composition and the low $\mathrm{C}: \mathrm{N}$ ratio of POM indicate that contributions of allochtonous organic material are limited. At active vent sites, such as those studied here, local production of organic matter likely by far exceeds allochtonous inputs from sedimentation and advection. The allochtonous input is probably mostly inorganic.

\section{Detrital organic matter}

While microbial autotrophic fixation of vent fluid DIC is likely the major source of vent particulate organic carbon, microbial biomass only represented a minor fraction of the sampled particulate organic matter. Considering the very low ATP and bacterial cell contents measured (Table 2), the actual microbial and bacterial fractions are most certainly low even if sampling induced some mortality. The predominance of non-living carbon is coherent with observations of abundant amorphous material and animal remains in all samples (Fig. 2). The detrital fraction of vent POM therefore appears to be substantial at the studied locations.

The vent faunal biomass, which is comparable to or higher than that of the most productive marine ecosystems (Sarrazin \& Juniper 1999), likely produces large quantities of detritus contributing to the POM pool. In particular, shed mucous secretions may represent an important contribution of non-living organic matter to the vent particulate matter pool. The alvinellid polychaete Paralvinella palmiformis excretes abundant quantities of mucus, likely for epidermal protection and detoxification (Juniper et al. 1986). Mucus was reported to account for $25 \%$ of a $2 \mathrm{~kg}$ wet weight biomass sample from an Axial Volcano vent site (Tunnicliffe et al. 1985). P. palmiformis mucus has a low C:N ratio (average $=4.6$; Juniper et al. 1986); thus, it could be a significant source of non-living, nitrogen-rich organic matter. Other alvinellids $(P$. sulfincola and $P$. pandorae) produce mucus-based, nitrogen-rich sheathed tubes (Morineaux et al. 2002), and shredded remains of these structures were observed in our POM samples. Other potential sources of detrital organic matter include faunal mortality (in particular of the sessile, biomass-dominant tubeworms) caused by abrupt shifts in temperature and composition of the vent fluid, and bacterial exudates that sometimes produce biofilms covering mineral and biological structures.

Detrital organic matter has been shown to be quantitatively important at vents elsewhere. Based on analyses of lipid classes in particulate matter from 5 to $40^{\circ} \mathrm{C}$ vents of the East Pacific Rise $\left(21^{\circ} \mathrm{N}\right)$, Comita et al. (1984) concluded that copepods, amphipods and macrofaunal invertebrates (and detritus derived from these organisms) constituted the major proportion of particulate organic matter. At $13^{\circ} \mathrm{N}$ on the East Pacific Rise, Albéric (1986) argued that the amino acid composition of POM reflected a large contribution of detritus derived from vestimentiferan and alvinellid biomass. Other studies (e.g. Brault 1984, Daumas et al. 1988, Juniper 1988) also suggest that detrital material may be a significant component of particulate matter at other vents in the Pacific. It is likely that detrital organic matter is particularly important in vent systems of the Eastern Pacific that are colonised by organisms shedding mucus or producing mucus-based tubes (such as alvinellid polychaetes), as well as by vestimentiferan tubeworms creating bushes where particulate detritus can accumulate. Detrital material may be quantitatively less important in systems lacking these 2 characteristics, such as vents in the Atlantic and some vents in the Pacific.

The small bacterial fraction observed here and in other studies may reflect a rapid turnover rate of bacterial biomass in the vent POM pool compared to other components such as detritus. Free-living primary productivity is assumed to be intense at vents but bacterial biomass may be kept at low levels by bacterial mortality and grazing by micro- and macro-consumers. Ultimately, the production and consumption of detritus by vent consumer species must be supported by a resupply of new organic matter from primary producers. This detritus likely fuels heterotrophic microbial activity and may play a major role in organic matter cycling 
at vents. Despite the recognition of a diverse heterotrophic microbiota at vents, to our knowledge the existence and functioning of a heterotrophic microbial food web has never been specifically investigated.

Previous studies of diffuse (Levesque \& Juniper 2002) and chimney-hosted vents (Sarrazin et al. 2002) suggested that organic detritus accumulates and POM becomes more heterotrophic as a vent site ages. In this study, the large inter-site variability in POM composition conceals any potential temporal variability. It is likely that site-specific differences in physico-chemical conditions and biotic assemblage composition constrain POM composition by affecting rates of primary production as well as detritus production and consumption.

\section{Implications for vent consumers}

POM feeding is an important trophic strategy for the non symbiont-containing hydrothermal vent fauna (Desbruyères \& Laubier 1986, McHugh 1987, Tunnicliffe et al. 1993, Van Dover \& Fry 1994, Chevaldonné 1996, Grelon 2001, Colaço et al. 2002, Morineaux et al. 2002). A concomitant stable isotope-based study of food webs at Axial Volcano (C. Levesque, S. K. Juniper \& H. Limén unpubl. data) shows that the POM described here is a major nutritional source of organic matter for the fauna.

The low organic content of vent PM implies that vent suspension- and deposit-feeders should be adapted to processing large volumes of organic-poor material, as are consumers in most sedimentary environments. However, the nutritional quality of our vent POM samples was superior to that of deep-sea sediments, as indicated by the lower $\mathrm{C}: \mathrm{N}$ ratios.

POM protein and lipid contents were positively correlated, as might be expected for these 2 macromolecular indicators of the labile and usually more nutritional fraction of POM. However, lipids and proteins only accounted for a small fraction of the bulk particulate organic carbon and nitrogen. Lipids (average content $=39.3 \mathrm{mg} \mathrm{g}^{-1} \mathrm{C}$ ) accounted for less than $4 \%$ of organic carbon (even if lipids were assumed to be composed exclusively of carbon). Hydrolysable proteins (average $=227.2 \mathrm{mg} \mathrm{g}^{-1} \mathrm{C}$ ) represented an average of $12 \%$ of organic carbon and $24 \%$ of nitrogen, assuming that proteins are $53 \% \mathrm{C}$ and $17 \% \mathrm{~N}$ (Sterner \& Elser 2002). This indicates that a significant part of the particulate nitrogen may not be available to the fauna. Non-hydrolysable proteins and mucopolysaccharides, such as those found in the mucus of alvinellid polychaetes (Juniper et al. 1986), may account for a significant part of the remaining organic carbon and nitrogen. Non-characterizable organic matter may also represent a large part of the organic fraction, as is often the case in sediment.

Bacterial abundance (and hence availability as a food source) was higher in more labile and nutritionally-rich POM (based on protein content and the C:N ratio; Table 3) but remained low overall. Although standing stocks alone cannot establish the importance of nutritional sources for consumers, the large abundance of detrital material observed here and in other investigations suggests that organic detritus is potentially a quantitatively important food source for the non symbiont-containing vent fauna. Measurements of the productivity of autotrophic bacteria (i.e. turnover of living microbial carbon) would provide a better estimate of their availability as a potential direct food source for vent consumers, and as a source for the POM pool.

\section{CONCLUSION}

Axial Volcano diffuse vents host a complex and heterogeneous particulate organic matter pool. The bulk of POM is apparently derived from local microbial primary production, yet bacterial biomass constituted less than $1 \%$ of sampled POM and is likely insufficient to provide a pure bacterial diet to consumers, without invoking a very rapid turnover of microbial biomass. Only species selectively feeding on pure bacterial mats or on autotrophic bacteria and archaea in the complex POM matrix can operate as strict primary consumers. It is not likely that most species can achieve such a degree of selective feeding. As POM is a complex mixture of autotrophic and heterotrophic microbial cells and detritus, most suspension- and deposit-feeders may include a significant part of detrital organic matter in their diet. In this case, a substantial contribution of autotrophic microbial productivity to the detrital pool would be required in order for the ecosystem to operate sustainably. The assumption that non symbiontcontaining vent fauna directly relies on a free-living autotrophic microbial diet may not represent the actual complexity of the trophic links between vent primary producers and consumers. The largely overlooked detrital compartment should be considered in future studies of the trophic ecology and organic matter cycling at hydrothermal vents.

Acknowledgements. We wish to thank chief scientist R.W. Embley and participants of the New Millennium Observatory (NeMO) project, as well as D. Grelon, R.J. Léveillé, M. Morineaux, A. Adamowicz, Z. Bourass, R. Mineau and D. Papineau for their help in sampling and analyses. G.J. Massoth and D.A. Butterfield provided vent fluid temperature data. We also thank the ROPOS team and the crews of the NOAA RV 'Ronald H. Brown' and of the University of Washington RV 'Thomas G. Thompson' for their support at sea. We 
acknowledge the comments of 4 anonymous reviewers which substantially improved an earlier version of this manuscript. This work was supported by the Natural Sciences and Engineering Research Council of Canada (NSERC) and the Fonds québécois de la recherche sur la nature et les technologies (FQRNT). C.L. was supported by post-graduate scholarships from NSERC, FQRNT and Fisheries and Oceans Canada. H.L. was supported by a post-doctoral fellowship from CanRidge, a collaborative research opportunity funded by NSERC.

\section{LITERATURE CITED}

Albéric P (1986) Composition en acides aminés des particules en suspension autour des évents hydrothermaux (dorsale Est-Pacifique, $\left.13^{\circ} \mathrm{N}\right)$. Oceanol Acta 9:73-79

Barnes H, Blackstock J (1973) Estimation of lipids in marine animals and tissues: detailed investigation of the sulphophosphovanillin method for 'total' lipids. J Exp Mar Biol Ecol 12:102-118

Brault M (1984) Biogéochimie de la matière organique dans les environnements hydrothermaux le long de la dorsale Est-Pacifique, à $13^{\circ} \mathrm{N}$. $\mathrm{PhD}$ thesis, Université Pierre et Marie Curie, Paris

Brault M, Marty JC, Saliot A (1984) Fatty acids from particulate matter and sediment in hydrothermal environments from the East Pacific Rise, near $13^{\circ} \mathrm{N}$. Org Geochem 6: 217-222

Chase RL, Delaney JB, Karsten JL, Johnson HP and 6 others (Canadian American Seamount Expedition) (1985) Hydrothermal vents on an axial seamount of the Juan de Fuca Ridge. Nature 313:212-214

Chevaldonné P (1996) Écologie des cheminées hydrothermales actives. PhD thesis, Centre Océanologique de Marseille, Marseille

Colaço A, Dehairs F, Desbruyères D (2002) Nutritional relations of deep-sea hydrothermal fields at the Mid-Atlantic Ridge: a stable isotope approach. Deep-Sea Res I 49: 395-412

Comita PB, Gagosian RB, Williams PM (1984) Suspended particulate organic material from hydrothermal vent waters at $21^{\circ} \mathrm{N}$. Nature 307:450-453

Daumas R, Albéric P, Brault M, Khripounoff A, Hermin MN, Marty JC, Salio A (1988) Matière organique présente dans les eaux d'un site hydrothermal actif du Pacifique-Est $\left(13^{\circ} \mathrm{N}\right)$. Oceanol Acta Spec. no 8:31-43

Desbruyères D, Laubier L (1986) Les Alvinellidae, une famille nouvelle d'annélides polychètes inféodés aux sources hydrothermales sous-marines: systématique, biologie et écologie. Can J Zool 64:2227-2245

Ehleringer JR, Rundel PW (1989) Stable isotopes: history, units and instrumentation. In: Rundel PW, Ehleringer JR, Nagy KA (eds) Stable isotopes in ecological research. Springer Verlag, New York, p 1-15

Embley RW, Murphy KM, Fox CG (1990) High resolution studies of the summit of Axial Volcano. J Geophys Res 95: 12785-12812

Embley RW, Chadwick WW Jr, Clague D, Stakes D (1999) 1998 eruption of Axial Volcano: multibeam anomalies and sea-floor observations. Geophys Res Lett 26:3425-3428

Fisher CR (1995) Toward an appreciation of hydrothermalvent animals: their environment, physiological ecology, and tissue stable isotope values. In: Humphris SE, Zierenberg RA, Mullineaux LS, Thomson RE (eds) Seafloor hydrothermal systems: physical, chemical, biological, and geochemical interactions. Geophys Monogr Ser 91: 297-316
Folch J, Lees M, Stanley GHS (1957) A simple method for the isolation and purification of total lipids from animal tissues. J Biol Chem 226:497-509

Grelon D (2001) Ecologie et éthologie de Paralvinella sulfincola, polychète des sources hydrothermales profondes du Pacifique nord-est. MSc thesis, Université du Québec à Rimouski, Québec

Grémare A, Amouroux JM, Charles F, Dinet A and 7 others (1997) Temporal changes in the biochemical composition and nutritional value of the particulate organic matter available to surface deposit-feeders: a two-year study. Mar Ecol Prog Ser 150:195-206

Juniper SK (1988) Géochimie et écologie d'un microenvironnement hydrothermal: les sécrétions de mucus de Paralvinella palmiformis. Oceanol Acta Spec. no 8:167-172

Juniper SK, Thompson JAJ, Calvert SE (1986) Accumulation of minerals and trace elements in biogenic mucus at hydrothermal vents. Deep-Sea Res 33:339-347

Karl DM (1980) Cellular nucleotide measurements and applications in microbial ecology. Microbiol Rev 44:739-796

Karl DM (1993) Total microbial biomass estimation derived from the measurement of particulate adenosine-5'triphosphate. In: Kemp PF, Sherr BF, Sherr EB, Cole JJ (eds) Current methods in aquatic microbial ecology. Lewis Publishers, Boca Raton, FL, p 359-368

Karl DM (1995) Ecology of free-living, hydrothermal vent microbial communities. In: Karl DM (ed) The microbiology of deep-sea hydrothermal vents. CRC Press, Boca Raton, FL, p 36-124

Levesque C, Juniper SK (2002) Particulate matter as a food source at a nascent hydrothermal vent on the Juan de Fuca Ridge. Cah Biol Mar 43:289-292

Marcus J (2003) Community ecology of hydrothermal vents at Axial Volcano, Juan de Fuca Ridge, northeast Pacific. PhD thesis, University of Victoria, Victoria, BC

Massoth GJ, Butterfield DA, Lupton JE, McDuff RE, Lilley MD, Jonasson IR (1989) Venting of phase-separated hydrothermal fluids at Axial Volcano, Juan de Fuca Ridge. Nature 340:702-705

Massoth GJ, Milburn HB, Johnson KS, Coale KH, Stapp MF, Meinig C, Baker ET (1991) A SUAVE (Submersible System Used to Assess Vented Emissions) approach to plume sensing: the Buoyant Plume Experiment at Cleft Segment, Juan de Fuca Ridge, and plume exploration along the EPR $9-11^{\circ} \mathrm{N}$. EOS Trans Am Geophys Union 72:234

Mayer LM, Schick LL, Setchell FW (1986) Measurement of protein in nearshore marine sediments. Mar Ecol Prog Ser 30:159-165

McHugh D (1987) The life-history patterns of two hydrothermal vent polychaetes, Paralvinella pandorae Desbruyères and Laubier and Paralvinella palmiformis Desbruyères and Laubier. MSc thesis, University of Victoria, Victoria, $\mathrm{BC}$

Morineaux M, Grelon D, Juniper SK (2002) Utilization of nutritional resources and energy budgets for populations of the hydrothermal vent polychaete Paralvinella sulfincola on Axial Volcano, Juan de Fuca Ridge (Northeast Pacific). Cah Biol Mar 43:241-244

Nelson DC, Wirsen CO, Jannasch HW (1989) Characterization of large, autotrophic Beggiatoa spp. abundant at hydrothermal vents of Guaymas Basin. Appl Environ Microbiol 55:2909-2917

Porter KG, Feig YS (1980) The use of DAPI for identifying and counting microflora. Limnol Oceanogr 25:943-948

Rau GH (1981) Hydrothermal vent clam and tubeworm ${ }^{13} \mathrm{C} /{ }^{12} \mathrm{C}$ : further evidence of non-photosynthetic food sources. Science 213:338-340 
Sarrazin J, Juniper SK (1999) Biological characteristics of a hydrothermal edifice mosaic community. Mar Ecol Prog Ser 185:1-19

Sarrazin J, Robigou V, Juniper SK, Delaney JR (1997) Biological and geological dynamics over four years on a hightemperature sulfide structure at the Juan de Fuca Ridge hydrothermal observatory. Mar Ecol Prog Ser 153:5-24

Sarrazin J, Juniper SK, Massoth G, Legendre P (1999) Physical and chemical factors influencing species distributions on hydrothermal sulfide edifices of the Juan de Fuca Ridge, northeast Pacific. Mar Ecol Prog Ser 190:89-112

Sarrazin J, Levesque C, Juniper SK, Tivey MK (2002) Mosaic community dynamics of Juan de Fuca Ridge sulfide edifices: substratum, temperature and implications for trophic structure. Cah Biol Mar 43:275-279

Sterner RW, Elser JJ (2002) Ecological stoichiometry: the biology of elements from molecules to the biosphere. Princeton University Press, Princeton, NJ

Tsurumi M (2001) Ecology of hydrothermal vents on three segments of the Juan de Fuca Ridge, northeast Pacific. PhD thesis, University of Victoria, Victoria, BC

Tsurumi M, Tunnicliffe V (2003) Tubeworm-associated com-

Editorial responsibility: Otto Kinne (Editor-in-chief), Oldendorf/Luhe, Germany munities at hydrothermal vents on the Juan de Fuca Ridge, northeast Pacific. Deep-Sea Res I 50:611-629

Tsurumi M, Tunnicliffe V, Marcus J (1998) Destruction and rebirth of the hydrothermal vent animal communities on Axial Volcano, Juan de Fuca Ridge. EOS Trans Am Geophys Union 79:F923

Tunnicliffe V, Juniper SK, de Burgh ME (1985) The hydrothermal vent community on axial seamount, Juan de Fuca Ridge. In Jones ML (ed) Hydrothermal vents of the Eastern Pacific: an overview. Bull Biol Soc Wash 6:453-464

Tunnicliffe V, Desbruyères D, Jollivet D, Laubier L (1993) Systematic and ecological characteristics of Paralvinella sulfincola Desbruyères and Laubier, a new polychaete (family Alvinellidae) from northeast Pacific hydrothermal vents. Can J Zool 71:286-297

Tunnicliffe V, McArthur AG, McHugh D (1998) A biogeographical perspective of the deep-sea hydrothermal vent fauna. Adv Mar Biol 34:353-442

Van Dover CL, Fry B (1994) Microorganisms as food resources at deep-sea hydrothermal vents. Limnol Oceanogr 39:51-57

Williams PM, Carlucci AF (1976) Bacterial utilization of organic matter in the deep-sea. Nature 262:810-811

Submitted: December 22, 2003; Accepted: October 21, 2004 Proofs received from author(s): March 8, 2005 